\title{
EFFECT OF ADDING POMEGRANATE PEELS TO GROWING JAPANESE QUAIL DIET ON PERFORMANCE, BLOOD AND IMMUNITY PARAMETRS
}

\author{
A.A. Abdel-Wahab ${ }^{1}$ and A.S. Mosad $^{2}$ \\ ${ }^{1}$ Poultry Production Department, Faculty of Agriculture, Fayoum University, 63514 Fayoum, Egypt. \\ ${ }^{2}$ Ministry of Agriculture.
}

(Received 17/9/2018, accepted 5/11/2018)

\section{SUMMARY}

$\mathrm{P}$ omegranate peel (PP) improved growth performance, nutrient digestibility and immunity moreover, reducing intestinal and fecal pathogenic microorganisms. So, the experimental work was designed to study the effects of PP powder as a natural feed additive on growing Japanese quails. Aggregate of 180 growing Japanese quail at ten days age were distributed into five groups, each group contain three replicates (12 birds each). The first group fed on basal control diet without any additives, the second group fed control diet plus sub-therapeutic dose of oxytetracyclin $(1 \mathrm{~g} / \mathrm{kg}$ diet). While, third, four and five groups fed on basal control diet with $0.5 \%, 1.0 \%$ and $1.5 \%$ PP powder respectively. The obtained results showed that: Pomegranate peel treatments significantly increased body weight $\left(\mathrm{LBW}_{38 \mathrm{~d}}\right)$, body weight gain $\left(\mathrm{BWG}_{10-38}\right)$ and performance index ( $\mathrm{PI}_{10-38}$ ), while, feed intake ( $\mathrm{FI}_{10-38}$ ) was significantly lower and feed conversion ( $\left.\mathrm{FC}_{10-38}\right)$ was significantly improved in all treated groups especially with $1.0 \% \mathrm{PP}$ level compared with antibiotic and control groups. Females had higher $\mathrm{LBW}_{38 \mathrm{~d}}, \mathrm{BWG}_{10-38}$, PI ${ }_{10-38}$ and best $\mathrm{FC}_{10-38}$ than males. Except both very low density lipoprotein and triglycerides serum biochemical indices such plasma total cholesterol, low density lipoprotein and high density lipoprotein significantly decreased by PP addition. The best antioxidant parameters (except Glutathione peroxidase) and immune responses and intestinal microflora count, favoring the quail fed diet supplemented with PP which had the best growth performance, especially $1.0 \%$ PP level. Quail fed diet containing $1.0 \%$ of PP had the lowest thiobarbaturic acid. Pomegranate peel (3\% and 1\%) supplementation desirably increased Lactobacillus count as compared with those fed diets appended with antibiotic and the control groups and decreased both E- coli and Salmonella counts compared to group of control. In conclusion, PP addition by $1.0 \%$ can improve productive and physiological parameters and also a good alternative to antibiotic for promoting quail growth.

Keywords: Quail nutrition, pomegranate peel, antibiotics, growing, performance, plasma constituents, immune responses, microflora.

\section{INTRODUCTION}

There are wastes production from fruits usually reinforced by some minerals, vitamins and other biological component and they a good provenance of fiber so. Compelling evidences vindicate and specify peel or extracts for much fruits as functional foods and nutraceuticals. Different sources for polyphenol (Sehm et al., 2011 and Benn et al., 2015) such as pomegranate and pomegranate peel (Bialonska et al., 2010) be obliged been found to progress growth of probiotic organisms in the hindgut, reduction different pathogens, causing higher production of fermentative metabolites which are useful for health. Also, several scientific studies have demonstrated the ability of these bioactive components as feed additives to improve growth performance, nutrient digestibility and immunity also, reducing intestinal and fecal pathogenic microorganisms and fecal noxious gas emissions (Yan et al., 2011, Abbas et al., 2017 and Ahmed and Yang, 2017).

Newly, attention has been increased highly in finding natural antioxidants for use in foods and medicine to substitute synthetic compounds which are being limited due to their carcinogenicity. Human body can be conserving from free radicals and arrest the progress of many chronic diseases as well as retard lipid oxidative rancidity in food by using natural antioxidants (Jang et al., 2010). The preventative impact of 
vegetables and fruits has been referred to the presence of antioxidants, especially antioxidant vitamins including $\alpha$-tocopherol, $\beta$-carotene and ascorbic acid (Prior and Cao, 2000). Phenolic or polyphenols including flavonoid, commonly found in eaten plants, have received major interest due to their biological functions such as antitumor, anti-mutagenic and antioxidant activities (Othman et al., 2007). Phenolic compounds act as reducing agents, hydrogen donors, singlet oxygen quenchers or metal chelators is mainly due to their antioxidant properties (Balasundram et al., 2006). In many different cultures and countries for thousands of years pomegranate fruits have been widely used, pomegranate juice and peel contained a lot of essential polyphenols such as ellagic tannins, ellagic acid and gallic acid (Loren et al., 2005). Pomegranate peel considered as a polyphenol-rich source, where containing high levels of flavonoids and tannins, such as punicalin, pedunculagan, gallagic acid, ellagic acid, and its esters of glucose (Kaneria et al., 2012 and El Din et al. 2014).

Pomegranate polyphenols contain flavonoids such as anthocyanins, flavonols and flavanols, compressed tannins like proanthocyanidins, ellagitannins and gallotannins that called hydrolysable tannins. The antioxidant effect of flavonoids acquired from pomegranate and its juice was punctate to be preferable or near to that of green tea and butylated hydroxyanisole. Pomegranate extract consists of admixture different phytochemicals, comprehensive the punicalagins, a kind of tannins adorable to pomegranates that have been shown to control free radical scavenging properties (Gil et al., 2000 and Noda et al., 2002). Schubert et al. (1999) displayed that the antioxidant activity was lower for empirical juices that were acquired from the arils only compared to mercantile juices that were obtained from whole pomegranates. Pomegranate is a strong anticancer factor that source the creation of apoptosis and cell cycle stopping in cancer cells, suppression of multiple signaling pathways in cancer cells and repression of tumorigenesis in animal models of various carcinomas (Mehta and Lansky, 2004; Jeune et al., 2005 and Abu Hajleh and Al-Dujaili, 2016). Pomegranate peel powder is a byproduct of juice production industries containing a series of bioactive compounds such as minerals and fibers use for a wide range in dietary requests (Mirdehghan and Rahemi, 2007). The waste produce from fruit holds up relatively higher total phenolic concentration $(1.261 \%)$ moreover to its properties as committing source for crude fibers (12.17\%) and inorganic remains that health promotive countenance like prevention from the development of cardiovascular disorders, hypoglycemic, apoptotic, anti-inflammatory, anti-parasitic and as prebiotic (Abdel-Rahim et al., 2013 and Anderson et al., 2009). Also, Ellagitannin that isolated from pomegranate peel an active antioxidant compounds and anticancer activities responsible for protecting low density lipoprotein, cholesterol from oxidation in vivo a key step in the pathogenesis of atherosclerosis.

Bialonska et al. (2009) appeared that pomegranate polyphenols have positive effects on health-promoting bacteria (Bifidobacterium breve and B. infantis) besides inhibitory effects on pathogenic bacteria (clostridia and Staphyloccocus aureus). In addition, pomegranate polyphenols have resulted in modified metabolism for gut bacteria (Bialonska et al., 2010). Also, the antibiotic activity for pomegranate returned to phenolic compounds particularly ellagic acid and punicalagin (Sarkhosh et al., 2007). In recent decades, Japanese quail become an important experimental bird for scientific studies, because of short life period furthermore, greater resistance to many poultry diseases, and increasing consumption of meats and eggs, and represents an alternative to chicken production (Berto et al., 2008; Cardozo et al., 2010 and Jatoi et al., 2013). So, the aims of this research was to define the effect of using three levels from pomegranate peel on performance, blood biochemical, blood antioxidant, immune responses and some microflora of intestinal in growing Japanese quails.

\section{MATERIALS AND METHODS}

The experimental work of the present study was carried out at the Poultry Research Station, Poultry Production Department, Faculty of Agriculture, Fayoum University to evaluate pomegranate peel powder as a feed additive in growing Japanese quails.

\section{Experimental design:}

\section{Birds and diets:}

A total number of 180 one day-old unsexed Japanese quail birds were used in this experiment and were initially fed a control diet (containing about $24 \% \mathrm{CP}$ and $2900 \mathrm{Kcal} \mathrm{ME} / \mathrm{Kg}$ ) for ten days, according to 
the requirement published by NRC (1994) At the end of $10^{\text {th }}$ day of age, the birds were wing-banded and randomly divided into five experimental groups each in three replicates (12 birds each).

Birds were individually weighed and placed in electrically heated battery till the end of experiment. The first group was fed basal control diet without any additives, the second fed control diet plus sub-therapeutic dose of oxytetracyclin, $1 \mathrm{~g} / \mathrm{kg}$ diet. While, third, four and five groups fed on basal control diet with $0.5 \%, 1.0$ $\%$ and $1.5 \%$ from pomegranate peel powder, respectively. The basal diet composition is presented in Table (1). Chicks were exposed to continuous lighting, feed and watered ad libitum. In 31 day of age birds were vaccinated against Newcastle virus (Lasota) by projection at eye.

Table (1): Feed ingredients and chemical composition of basal experimental diet.

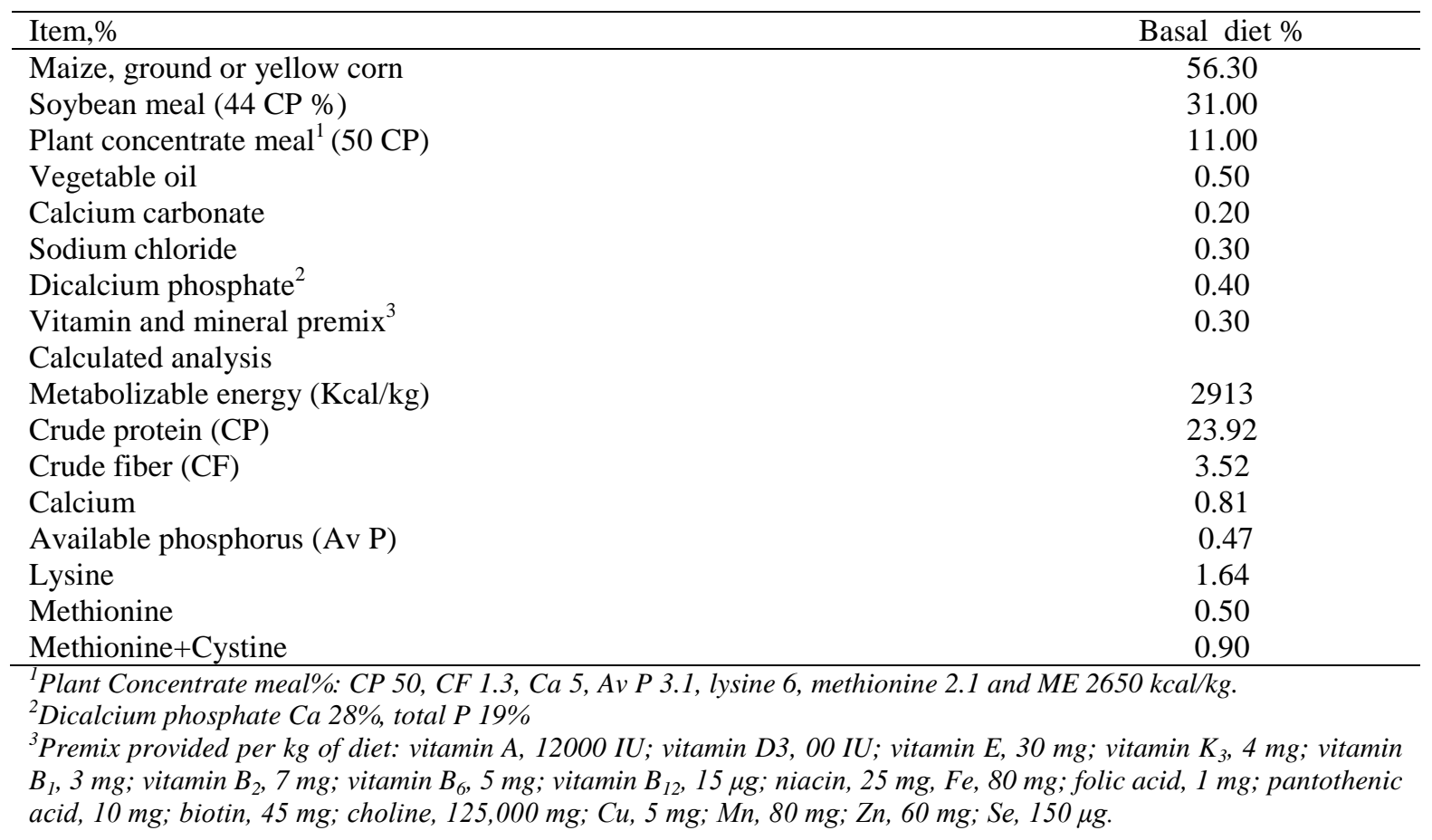

\section{Growth Performance:}

Live body weight of chicks (LBW) were individually weighed and feed consumption per cage were weekly recorded (FI), the uneaten feed discarded, body weight gain (BWG, g) as follows: $\mathrm{BWG}_{10}$ to $38=$ $\mathrm{LBW}_{38}-\mathrm{LBW}_{10}$, feed conversion ratio (FCR) and performance index (PI, 10 to 38 ) based on North (1981) formula was calculated as follows: PI = LBW, $\mathrm{kg} / \mathrm{FCR} \times 100$.

\section{Blood biochemical, antioxidant and immunity:}

Individual 20 blood samples were collected in dry clean centrifuge tubes at slaughter and serum was separated by centrifugation at $3000 \mathrm{rpm}$ for 15 minutes and assigned for subsequent determination. Quantitative determinations were done for the following: total cholesterol (Chol), high density lipoproteins (HDL), low density lipoproteins (LDL), very low density lipoproteins (VLDL) and triglycerides (Trig). All blood biochemical parameters were calorimetrically determined using commercial diagnosing kits (produced by Spectrum Diagnostics Company, Egypt). The glutathione peroxidase (GPx, EC 1.11.1.9) was calorimetrically determined according to Paglia and Valentine (1967) and thiobarbaturic acid- reactive substances' (TBARS) were performed according to Yagi (1998)_using commercial diagnosing kits produced by Cayman Chemical Company (USA). The method used for the assay of chicken Immunoglobulins Isotypes IgG, IgM, and IgA in Sandwich ELISA described by Erhard et al. (1992) the absorbance measured on an ELISA plate reader set at $450 \mathrm{~nm}$. 


\section{Microbial analysis:}

Immediately after slaughter, intestinal content was collected in sterile glass containers, digesta was evacuated and mixed. The sealed containers were kept in the laboratory at $4^{\circ} \mathrm{C}$ till enumeration of microbial population. Samples (1g of the mixed fresh mass) were taken into sterile test tubes, diluted 1:10 in sterile $0.1 \%$ peptone solution and homogenized for three $\mathrm{min}$ in a Stomacher homogenizer. Ten fold serial dilutions up to $10^{-7}$ of each sample were prepared in nine $\mathrm{ml}$ of $0.1 \%$ sterile peptone solution. Viable counts of Salmonella ssp, E. coli and Lactobacilli ssp were performed. One milliliter of the serial dilution was incubated into sterile Petri dishes and sealed with an appropriate medium. Lactobacillus spp. colony count was determined using MRS agar (Biokar Diagnostic, France) after incubation in an anaerobic chamber at $37^{\circ} \mathrm{C}$ for $72 \mathrm{~h}$. Salmonella and E. coli colonies were counted on brilliant green agar plate and incubated at $37^{\circ} \mathrm{C}$ for $24 \mathrm{~h}$ ). After cultivation in Petri dishes, the total colony count for Lactobacilli, Salmonella and E. coli was then calculated as the number of colonies by reciprocal of the dilution. The microbial counts were determined as colony forming units (cfu) per gram of sample.

\section{Statistical analysis:}

Using General Linear Models (GLM) procedure of SPSS (2013) studied traits were subjected to a twoway analysis of variance with treatment and sex as main effects as follows:

$$
Y_{i j k}=\mu+T_{i}+S_{j}+e_{i j k} \text {. }
$$

Where: $\mathrm{Y}_{\mathrm{ijk}}$ : Observed value in the $\mathrm{i}^{\text {th }}$ treatment of the $\mathrm{j}^{\text {th }}$ sex of the $\mathrm{k}^{\text {th }}$ individual, $\mu$ : overall mean, $\mathrm{T}_{\mathrm{i}}$ : treatment effect (i: 1 to 5), $S_{j}$ : sex effect (j: 1 and 2) and $e_{i j k}$ : random error term. When significant $F$ values were obtained main effects means were compared by Duncan's new multiple range tests (Duncan, 1955).

\section{RESULTS AND DISCUSSIONS}

Data presented in Table 2 showed that quails fed diet supplemented with $1.0 \%$ PP had the heaviest $\mathrm{LBW}_{38 \mathrm{~d}}, \mathrm{BWG}_{10-38}$, better FC ${ }_{10-38}$ and higher PI ${ }_{10-38}(P \leq .001)$ and nearly less $\mathrm{FI}_{10-38}$ compared with other treatments studied (control and antibiotic groups). Significant sex effects were shown for $\mathrm{LBW}_{38} \mathrm{~d}, \mathrm{BWG}_{10-}$ 38, $\mathrm{FC}_{10-38}$ and $\mathrm{PI}_{10-38}$ favoring females.

Table (2): Effects of treatment and sex on growth traits in Japanese quail (Main effects \pm SE).

\begin{tabular}{|c|c|c|c|c|c|c|}
\hline Item & $\mathrm{LBW}_{10 \mathrm{~d}}$ & $\mathrm{LBW}_{38 \mathrm{~d}}$ & $\mathrm{BWG}_{10-38}$ & $\mathrm{FI}_{10-38}$ & $\mathrm{FC}_{10-38}$ & $\mathrm{PI}_{10-38}$ \\
\hline \multicolumn{7}{|l|}{ Treatment effect: } \\
\hline Control diet (C) & $60.20 \pm 1.18$ & $208.31 \pm 2.80^{\mathrm{c}}$ & $148.11 \pm 2.45^{\mathrm{c}}$ & $636.07 \pm 0.81^{\mathrm{a}}$ & $4.38 \pm 0.06^{\mathrm{a}}$ & $4.92 \pm 0.17^{\mathrm{d}}$ \\
\hline $\mathrm{C}+$ oxytetracyclin $1 \mathrm{~g} / \mathrm{kg}$ diet & $59.92 \pm 1.19$ & $213.08 \pm 2.81^{\mathrm{c}}$ & $153.17 \pm 2.46^{\mathrm{c}}$ & $631.03 \pm 0.81^{\mathrm{b}}$ & $4.17 \pm 0.06^{\mathrm{b}}$ & $5.23 \pm 0.17^{\mathrm{d}}$ \\
\hline $\mathrm{C}+0.5 \% \mathrm{PP}$ & $60.15 \pm 1.21$ & $233.68 \pm 2.86^{\mathrm{b}}$ & $173.54 \pm 2.51^{\mathrm{b}}$ & $597.44 \pm 0.83^{\mathrm{c}}$ & $3.46 \pm 0.06^{\mathrm{c}}$ & $6.82 \pm 0.17^{\mathrm{c}}$ \\
\hline $\mathrm{C}+1.0 \% \mathrm{PP}$ & $60.52 \pm 1.20$ & $253.44 \pm 2.83^{\mathrm{a}}$ & $192.91 \pm 2.48^{\mathrm{a}}$ & $563.66 \pm 0.82^{\mathrm{d}}$ & $2.94 \pm 0.06^{\mathrm{e}}$ & $8.73 \pm 0.17^{\mathrm{a}}$ \\
\hline $\mathrm{C}+1.5 \% \mathrm{PP}$ & $59.96 \pm 1.36$ & $234.05 \pm 3.22^{\mathrm{b}}$ & $174.08 \pm 2.83^{\mathrm{b}}$ & $547.30 \pm 0.93^{\mathrm{e}}$ & $3.16 \pm 0.07^{\mathrm{d}}$ & $7.47 \pm 0.19^{b}$ \\
\hline $\mathrm{P}$ & 0.9971 & $<0.0001$ & $<0.0001$ & $<0.0001$ & $<0.0001$ & $<0.0001$ \\
\hline \multicolumn{7}{|l|}{ Sex effect: } \\
\hline Females & $62.47 \pm 0.69^{\mathrm{a}}$ & $238.69 \pm 1.64^{\mathrm{a}}$ & $176.22 \pm 1.44^{\mathrm{a}}$ & $595.00 \pm 0.47$ & $3.47 \pm 0.04^{\mathrm{b}}$ & $7.26 \pm 0.10^{\mathrm{a}}$ \\
\hline Males & $57.83 \pm 0.86^{\mathrm{b}}$ & $218.33 \pm 2.02^{\mathrm{b}}$ & $160.51 \pm 1.77^{\mathrm{b}}$ & $595.19 \pm 0.58$ & $3.77 \pm 0.05^{\mathrm{a}}$ & $6.01 \pm 0.12^{b}$ \\
\hline $\mathrm{P}$ & $<0.0001$ & $<0.0001$ & $<0.0001$ & 0.7988 & $<0.0001$ & $<0.0001$ \\
\hline
\end{tabular}

These results are in accordance with those reported by Azoz and Basyony (2012) when pomegranate dried waste was included in diets of mature does at levels of 0.5, 1.0 and 1.5\%. In the same trend Mady et al. (2016) showed that rabbits fed diet of $1.5 \%$ and $3 \%$ pomegranate peel powder (ppp) recorded the highest values of daily weight gain as compared to those fed the control diet (27.16 and $27.02 \mathrm{vs.21.71} \mathrm{gm)} \mathrm{and} \mathrm{FC}$ 
was improved (1.10 and 1.09 vs.1.27) and increasing significantly final body weight, BWG and PI, appreciable improvement of FC. Similarly, Yassein et al. (2015) observed that quails fed on diet supplemented with 10 and $15 \mathrm{~g} \mathrm{PPP} / \mathrm{kg}$ diet had significant $(\mathrm{P} \leq 0.01)$ increased BWG compared to butylated hydroxy toluene supplemented diet and the control group. While, there was a significant $(\mathrm{P} \leq 0.05)$ decrease in FI and FC in all treated groups. Tannins are astringent, bitter plant polyphenols, which react with salivary muco-protein or directly with taste receptors in the mouth, reducing palatability. Ahmed and Yang (2017) stated that inclusion of PGB in the broiler diet reduced the FI and improved FC values, the reduction in FI can be explained by reduced diet palatability due to the presence of a considerable amount of tannin in the experimental PGB (hydrolysable tannin $14.26 \mathrm{mg} / \mathrm{g}$ on a DM basis). Also, Ahmadipour et al. (2018) confirmed that in broiler. The highly rendering for pomegranate may be coming from ingredients of pomegranate that show health promoting influence out of the alteration of physiological and biochemical pathways. Recently evidences submitted that pomegranates fruits, peels and seeds clarify therapeutics modulations in health directing via inhibition of free radical effect and modulation of enzymes activity linked with diseases development and progression (Rahmani et al., 2017). In contrast, Abbas et al. (2017) showed that final body weight was similar among quails fed on treated diets by PPP, whereas, the highest FI was listed in quail that fed on diets with 7.5\% PPP; however, for 2.5 and $5.0 \%$ was insignificant affect FI as compared to control, and this agree with (Rajani et al., 2011 and Saki et al., 2014). This effect on BWG or even cause weight reduction could be attributed to several factors as pomegranate peel contains considerable amounts of polyphenols together with the high fiber content which reduced FI and the restricted calorie intake (Mahmoud et al., 2011); contains polyphenols may suppress growth of the adipose tissue through their anti-angiogenic activity and by modulating adipocyte metabolism or reduce fat digestion and absorption, nutrient digestibility (CP and NFE) and nutritive value of TDN, DE and DCP (Fayed et al., 2012).

Results in Table (3) showed that insignificant effect influenced all serum biochemical indices studied $(P>0.05)$. All serum biochemical indices significantly affected by sex, except total VLDL and Trig. Females had higher total Chol, HDL and LDL $(P \leq 0.05)$ concentration than males.

Table (3): Serum biochemical indices at slaughter as affected by treatment and sex (Main effects \pm SE).

\begin{tabular}{|c|c|c|c|c|c|}
\hline Item & Total Chol, mgdl & HDL mgdl & LDL mgdl & VLDL mgdl & Trig mgdl \\
\hline \multicolumn{6}{|l|}{ Treatment effect } \\
\hline Control diet (C) & $211.75 \pm 14.16$ & $31.25 \pm 2.92$ & $145.75 \pm 9.34$ & $34.75 \pm 9.01$ & $149.50 \pm 44.21$ \\
\hline $\mathrm{C}+$ oxytetracyclin $1 \mathrm{~g} / \mathrm{kg}$ diet & $254.75 \pm 14.16$ & $35.50 \pm 2.92$ & $175.25 \pm 9.34$ & $44.00 \pm 9.01$ & $220.00 \pm 44.21$ \\
\hline $\mathrm{C}+0.5 \% \mathrm{PP}$ & $202.75 \pm 14.16$ & $28.50 \pm 2.92$ & $142.75 \pm 9.34$ & $31.50 \pm 9.01$ & $157.50 \pm 44.21$ \\
\hline $\mathrm{C}+1.0 \% \mathrm{PP}$ & $188.25 \pm 14.16$ & $32.50 \pm 2.92$ & $130.75 \pm 9.34$ & $25.00 \pm 9.01$ & $125.00 \pm 44.21$ \\
\hline $\mathrm{C}+1.5 \% \mathrm{PP}$ & $191.25 \pm 14.16$ & $29.50 \pm 2.92$ & $139.25 \pm 9.34$ & $22.50 \pm 9.01$ & $112.50 \pm 44.21$ \\
\hline $\mathrm{P}$ & 0.0571 & 0.53422 .92 & 0.0797 & 0.4512 & 0.4725 \\
\hline \multicolumn{6}{|l|}{ Sex effect } \\
\hline Females & $230.42 \pm 8.17^{\mathrm{a}}$ & $37.33 \pm 1.68^{\mathrm{a}}$ & $159.58 \pm 5.39^{\mathrm{a}}$ & $33.50 \pm 5.20$ & $160.00 \pm 25.52$ \\
\hline Males & $185.67 \pm 8.17^{\mathrm{b}}$ & $26.50 \pm 1.68^{\mathrm{b}}$ & $133.58 \pm 5.39^{\mathrm{b}}$ & $25.58 \pm 5.20$ & $127.33 \pm 25.52$ \\
\hline $\mathrm{P}$ & 0.0022 & 0.0007 & 0.0052 & 0.3028 & 0.3833 \\
\hline
\end{tabular}

Babu and Srinivasan (1997) reported that Chol and LDL were decreased significantly as compared with control by PP treatments, which may be due to mediated motivation of hepatic cholesterol-7- hydroxylase activity. While, PP significantly $(\mathrm{P}<0.01)$ increased HDL and the ratio of HDL/LDL in the blood of doe rabbits feeding on diets contains PP, thus play important and positive role in the treatment of lipid metabolic unrest and obesity. Aviram and Rosenblat (2013) found that PP has good protection for high-density lipoprotein from oxidation compared to other antioxidants. Additionally, PP has the ability to stimulate HDL-associated paraoxonase 1, which depredated harmful oxidized lipids in lipoproteins (Fuhrman et al., 2005 and Rosenblat et al., 2006). Dietary PP modulate fat metabolism (Medjakovic and Jungbauer, 2013). In fact, blood Chlo levels were decreased by PP consumption (Aviram et al., 2008). Many action mechanisms might explain these effects. Among them one can that include metabolic effects such as: (1) suppression of 
energy intake and inhibition of pancreatic lipase activity, leading to decreased absorption of fat (Lei et al., 2007), (2) changing the interplay between the metabolic hormones leptin and insulin (decrease of both) and adiponectin (increase) (McFarlin et al., 2009). Al-Moraie et al. (2013) who showed that oral treatment for hypercholesterolemic rats by pomegranate juice were significantly increased HDL levels and antioxidant enzymes as compared with the control positive group. Also, the same results were found by (Yassein et al., 2015 and Abbas et al., 2017) in quails. Results founded by (Sharifiyan et al., 2016) showed no significant differences are observed in total Chlo, Trig, LDL, HDL and VLDL for treatment groups in comparison with hypercholesterolemic control.

All Antioxidant parameters and immune responses studied were significantly affected (Table 4) by treatment effect (except GPx). Quail fed the diet supplemented with $1.0 \% \mathrm{PP}$ had the highest $\operatorname{Ig}_{\mathrm{G}}$, higher $\operatorname{Ig}_{\mathrm{A}}$ and $\operatorname{Ig}_{M}$ but the lower thiobarbaturic acid (TBAR) followed by those fed the diet supplemented with $1.5 \%$ PP, $0.5 \%$ PP and control. On the contrary, antioxidant parameters and immune responses tested insignificantly affected by sex (Table 4).

Table (4): Antioxidant parameters and Immune response as affected by different dietary treatments and sex (Main effects \pm SE).

\begin{tabular}{|c|c|c|c|c|c|}
\hline \multirow{2}{*}{$\begin{array}{l}\text { Item } \\
\text { Treatment effect }\end{array}$} & \multicolumn{2}{|c|}{ Antioxidant parameters } & \multicolumn{3}{|c|}{ Immune response } \\
\hline & & & & & \\
\hline & GPXnmolminmgprotien & TBAR $\mu g g$ & IgGmgdl & IgA mgdll & IgMmgdll \\
\hline Control diet (C) & $1864.50 \pm 117.03$ & $1.53 \pm 0.10^{\mathrm{a}}$ & $947.63 \pm 35.26^{\mathrm{cd}}$ & $95.12 \pm 4.25^{\mathrm{ab}}$ & $181.70 \pm 7.96^{\mathrm{ab}}$ \\
\hline $\mathrm{C}+$ oxytetracyclin $1 \mathrm{~g} / \mathrm{kg}$ diet & $1683.75 \pm 117.03$ & $1.50 \pm 0.10^{\mathrm{a}}$ & $902.08 \pm 35.26^{\mathrm{d}}$ & $86.07 \pm 4.25^{\mathrm{b}}$ & $164.72 \pm 7.96^{\mathrm{b}}$ \\
\hline $\mathrm{C}+0.5 \% \mathrm{PP}$ & $2068.50 \pm 117.03$ & $1.25 \pm 0.10^{\mathrm{ab}}$ & $978.33 \pm 35.26^{\mathrm{bc}}$ & $91.19 \pm 4.25^{\mathrm{ab}}$ & $174.33 \pm 7.96^{\mathrm{ab}}$ \\
\hline $\mathrm{C}+1.0 \% \mathrm{PP}$ & $2009.00 \pm 117.03$ & $1.15 \pm 0.10^{\mathrm{b}}$ & $1067.96 \pm 35.26^{\mathrm{a}}$ & $100.15 \pm 4.25^{\mathrm{ab}}$ & $191.14 \pm 7.96^{\mathrm{ab}}$ \\
\hline $\mathrm{C}+1.5 \% \mathrm{PP}$ & $1912.75 \pm 117.03$ & $1.16 \pm 0.10^{\mathrm{b}}$ & $1053.38 \pm 35.26^{\mathrm{ab}}$ & $98.70 \pm 4.25^{\mathrm{ab}}$ & $188.40 \pm 7.96^{\mathrm{ab}}$ \\
\hline $\mathrm{P}$ & 0.1616 & 0.0069 & 0.0100 & 0.1019 & 0.1019 \\
\hline \multicolumn{6}{|l|}{ Sex effect } \\
\hline Females & $1859.42 \pm 67.57$ & $1.29 \pm 0.06$ & $1000.42 \pm 20.36$ & $94.90 \pm 2.45$ & $181.29 \pm 4.60$ \\
\hline Males & $1879.00 \pm 67.57$ & $1.22 \pm 0.06$ & $1018.85 \pm 20.36$ & $96.91 \pm 2.45$ & $185.05 \pm 4.60$ \\
\hline $\mathrm{P}$ & 0.8411 & 0.4071 & 0.5342 & 0.5731 & 0.5731 \\
\hline
\end{tabular}

The results obtained are consistent with Ahmed and Yang (2017) who indicated that dietary supplementation with Punica granatum L. by-product (PGB) led to a significant increase in serum IgA and IgG concentration relative to the control. Also, Sharifiyan et al. (2016) indicated that PP extract significantly increases serum antioxidant capacity in the extract recipient group in comparison with hypercholesterolemic control $(P<0.05)$. Wang et al. $(2000)$ reported that dietary supplementation with polyunsaturated fatty acid (PUFA), especially n-3 fatty acid, increased the growth of immune organs. Pomegranate seeds are a rich source of PUFA, particularly $\alpha$-linolenic acid, linoleic acid and conjugated $\alpha$ - linolenic acid (CLA) (Fadavi et al., 2006 and Melo et al., 2014). Dietary CLA is also reportedly a potent enhancer of IgG production (Kohno et al., 2004 and Yamasaki et al., 2004). Yamasaki et al. (2006) reported significantly enhanced IgG and IgM production in spleen lymphocytes of rats fed diet supplemented with pomegranate seed oils. In addition, ellagitannin (Ramstead et al., 2013) and a polysaccharide (PSP001) (Joseph et al., 2012) isolated from pomegranate peel was also found to have immunomodulatory activity via stimulation of the growth of normal lymphocytes. Also, Yassein et al. (2015) found that the TBARS values was significantly decreased in birds fed $15 \mathrm{~g} \mathrm{PP} / \mathrm{kg}$ compared with that received butylated hydroxy Toluene (BHT) supplemented diet and the control group and these results are consistent with our findings. Many antioxidant compounds that found in PP including, a precursor of ellagic acid and (a) ellagitannins have ability to lower malondialdehyde levels, Which, have antioxidative properties (Mass et al., 1991). Also, Zeweil et al. (2013) reported that lipid peroxide (malondialdehyde) levels decreased significantly to reach around $54 \%$ of the heat stressed bucks and value of PP were 1.5, 3.0 and $4.5 \%$ of PP dietary used. 
Dietary treatments represented useful and harmful intestinal bacteria (Table 5). Both 1.0 and $3.0 \%$ PP supplementation desirably increased Lactobacillus count and decreased both E- coli and Salmonella counts as compared with control group.

Table (5): Useful and harmful intestinal bacteria in growing quails as affected by different dietary treatments and sex (Main effects $\pm \mathrm{SE}$ ).

\begin{tabular}{lccc}
\hline Item & Lactobacillus $\log 10$ cfug & E coli $\log 10$ cfug & Salmonela $\log 10$ cfug \\
\hline Treatment effect: & & & \\
Control diet (C) & $5.21 \pm 0.24^{\mathrm{b}}$ & $7.29 \pm 0.25^{\mathrm{a}}$ & $7.04 \pm 0.30^{\mathrm{a}}$ \\
C+oxytetracyclin1 $\mathrm{g} / \mathrm{kg}$ diet & $4.63 \pm 0.24^{\mathrm{b}}$ & $4.80 \pm 0.25^{\mathrm{b}}$ & $5.23 \pm 0.30^{\mathrm{c}}$ \\
$\mathrm{C}+0.5 \% \mathrm{PP}$ & $5.96 \pm 0.24^{\mathrm{a}}$ & $6.46 \pm 0.25^{\mathrm{b}}$ & $6.27 \pm 0.30^{\mathrm{ab}}$ \\
$\mathrm{C}+1.0 \% \mathrm{PP}$ & $6.39 \pm 0.24^{\mathrm{a}}$ & $6.69 \pm 0.25^{\mathrm{ab}}$ & $6.21 \pm 0.30^{\mathrm{abc}}$ \\
$\mathrm{C}+1.5 \% \mathrm{PP}$ & $6.04 \pm 0.24^{\mathrm{a}}$ & $6.41 \pm 0.25^{\mathrm{b}}$ & $5.93 \pm 0.30^{\mathrm{bc}}$ \\
$\mathrm{P}$ & 0.0010 & 0.0003 & 0.0256 \\
Sex effect: & & & \\
Females & $5.99 \pm 0.14$ & $6.30 \pm 0.14$ & $5.80 \pm 0.17^{\mathrm{b}}$ \\
Males & $5.58 \pm 0.14$ & $6.24 \pm 0.14$ & $6.38 \pm 0.17^{\mathrm{a}}$ \\
$\mathrm{P}$ & 0.0600 & 0.7644 & 0.0353 \\
\hline E coli: Escherichia coli & cfug: logarithm of colony forming unit per gram of digesta \\
a...c: Means within the same column with different superscript, PP: Pomegranate peels. & \\
& &
\end{tabular}

The lowest number of $E$ - coli and Salmonella counts were shown for the group fed the diet supplemented with antibiotic whereas the control group had the highest harmful intestinal bacteria. Insignificant differences due to sex effect were obtained for useful and harmful intestinal bacteria studied except for Salmonella counts whereas males had higher than females. This results agree with Mady et al. (2016) who found that inclusion of pp whether $1.5 \%$ or $3 \%$ in the diet leads to marked improvement of caecal ecosystem through decreasing significantly numbers of pathogenic bacteria and justifying each of values, ammonia concentration and total volatile fatty acids profile in the caecum toward healthy circumstances. The antimicrobial action may be due tannins that found in PP the potency of tannin compounds to precipitate proteins, thus causing transpiration of cell membrane of the microorganism (Endo et al., 2010), and aiding cell lysis which ultimately leads to cell death. Also, may be due to the bactericidal and bacteriostatic effects of PP which confirmed by Viuda et al. (2010) due to its contents of phenolic, anthocyanine, gallic acid and hydrolysable tannins, (mainly punicalin, pedunculagin and punicalgin) by which the total bacterial count, $E$ coli and Clostridium spp in caecum content were reduced, then improved the intestinal microbial balance and in turn directed the fermentation pattern and its end products toward favorable circumstances. On the other hand, the essential oils contents of PP evidenced by Brenes et al. (2010) may be responsible for enhancing the production of digestive secretions, stimulating blood circulation, excreting antioxidant properties and reducing the level of pathogenic bacteria. Ahmed and Yang (2017) found that feeding on diets with PGB resulted a linear lowering in Salmonella spp and Escherichia coli. Also, PGB in diets reduced the $\mathrm{pH}$ in ileal digesta. Contrariwise, the concentration of Bacillus bacteria in cecal digesta were increased linearly in response to both levels of dietary PGB, while Salmonella and E. coli concentrations decreased when birds feeding on diets were supplemented by $1 \%$ PGB, as did cecal $\mathrm{pH}$. At 21 day the concentration of S. cerevisiae was increased by $1 \%$ PGB only, but at 35 day, fecal Bacillus concentration increased in both PGB levels. Fecal E. coli at 21 and 35 day was reduced by increasing levels of PGB, whereas Salmonella only at 21 day. Regarding the average of $48 \mathrm{~h}$, dietary PGB effectively reduced the emissions of ammonia and methanethiol from broiler excreta. In conclusion, the results suggest that, dietary PGB improved immunity and the intestinal microbial ecosystem of broilers along with reduced odorous gas emissions from excreta. In contrast, Yassein et al. (2015) concluded that there were no significant effects of PP and BHT on micro bacterial count in the small intestine. 


\section{Abdel-Wahab and Mosad}

\section{CONCLUSION}

Considering the results of the current study it could be concluded that supplementation of PP, particularly $1.0 \%$ level can improve productive, physiological parameters, antioxidant parameters, immune responses, intestinal microflora count and also a good alternative to antibiotic for promoting quail growth.

\section{REFERENCES}

Abbas, R.J., K.Ch.K. Al-Salhie and S.K.M. Al-Hummod (2017). The effect of using different levels of pomegranate (Punica granatum) peel powder on productive and physiological performance of Japanese quail (Coturnix coturnix japonica). Livestock Research for Rural Development 29 (12) 2017

Abdel-Rahim, E.A., H.S. El-Beltagi and R.M. Romela (2013). White Bean seeds and Pomegranate peel and fruit seeds as hypercholesterolemic and hypolipidemic agents in albino rats. Grasas y Aceites 64:50-58.

Abu Hajleh, M. and E. A. S. Al-Dujaili. (2016). "Anti-cancer activity of pomegranate and its biophenols; general review". EC Nutr. 6.1: 28-52.

Ahmadipour, B, S. Pat and F. Khajali (2018). The Protective effect of pomegranate peel powder on pulmonary hypertension in broiler chickens. J,S,M, Biomar 4,(1): 1013.

Ahmed, S.T. and C. J. Yang (2017). Effects of dietary punica granatum L. by products on performance, immunity, intestinal and fecal microbiology, and odorous gas emissions from excreta in broilers. J. Poult. Sci., 54: 157-166.

Al-Moraie, M.M.D., R. A. Arafat and A. A. Al-Rasheedi (2013). Effect of pomegranate juice on lipid profile and antioxidant enzymes in hypercholesterolemic rats. Life Sci J. 10 (3): 2717-2728 (ISSN: 1097- 8135).

Anderson, J.W, P. Baird, J. R.H. Davis, S. Ferreri, M. Knudtson, A. Koraym, V. Waters and C.L. Williams. (2009). Health benefits of dietary fiber. Nutr. Rev .67:188-205.

Aviram, M. and M. Rosenblat (2013). Pomegranate for your cardiovascular health. Rambam Maimonides Medical J.; 4 (2):e0013.

Aviram, M., N. Volkova, R. Coleman, M. Dreher, M.K. Reddy, D. Ferreira and M. Rosenblat (2008). Pomegranate phenolics from the peels, arils, and flowers are antiatherogenic: Studies in vivo in atherosclerotic apolipoprotein E-deficient (E0) mice and in vitro in cultured macrophages and lipoproteins. J. Agr. Food Chem., 56: 1148-1157. doi:10.1021/jf071811q.

Azoz, A. A. and Basyony (2012). Influence of supplementation of pomegranate dried waste as of natural ant oxidative potential source in feeding does rabbits on some productive and reproductive performance, under hot climate condition. Egyptian J. Rabbit Sci., 22 (1): 23 -39.

Babu, P. S. and K. Srinivasan (1997). Hypolipidemic action of curcumin, the active principle of turmeric (Curcuma longa) in streptozotocin induced diabetic rats. Molecular and cellular biochemistry, 166 (1-2): 169-175.

Balasundram, N., K. Sundram and S. Samman (2006). Phenolic compounds in plants and agri-industrial byproducts: antioxidant activity, occurrence and potential uses. Food Chem., 99: 191-203.

Benn, T, B. Kim, Y.K. Park, Y. Yang, T. X. Pham, C. S. Ku, and J.Y. Lee (2015). Polyphenol-rich blackcurrant extract exerts hypocholesterolaemic and hypoglycaemic effects in mice fed a diet containing high fat and cholesterol. Br. J. Nutr. 113: 1697-1703.

Berto, B.P, S.V. Cardozo, W.L. Teixeira-Filho, A.M.R. Ferreira and C.W.G. Lopes (2008). Aflatoxin effect on the oocysts morphometry and contribution on the morphology of Eimeria bateri Bhatia, Pandey and Pande, 1965 of the Japanese quail Coturnix japonica, in Brazil. Rev Bras Parasitol Vet: 17: 235-8.

Bialonska, D, P. Ramnani, S.G. Kasimsetty, K.R. Muntha, G.R. Gibson and D. Ferreira (2010). The influence of pomegranate by-product and punicalagins on selected groups of human intestinal microbiota. Int. J Food Microbiol, 140: 175-82. 
Bialonska, D, S.G. Kasimsetty, K.K. Schrader and D. Ferreira (2009). The effect of pomegranate (Punica granatum L.) byproducts and ellagitannins on the growth of human gut bacteria. J. Agric. Food Chem. $57,8344-8349$.

Brenes, A., A. Viveros, I. Goñi, C. Centeno, F. Saura-Calixto and I. Arija (2010). Effect of grape seed extract on growth performance, protein and polyphenol digestibilities, and antioxidant activity in chickens. Span. J. Agric. Res. 8(2): 326-333.

Cardozo, S.V., B.P. Berto, A.M.R. Ferreira, H.W. Macedo and C.W.G. Lopes (2010). Freque^ncia de eimeria bateri em codornas Japonesas (Coturnix japonica) desafiadas com dose sub-letal de aflatoxina. Rev. Bras Parasitol Vet; 32:211-4.

Duncan, D. B., (1955). The multiple ranges and multiple F Test. Biometrics.11: 1-42.

El Din, H.M.F., S. S. Mohamed and T.M. El-Messery (2014). Role of the functional food (pomegranateyoghourt) as hepatoprotective effect on liver injured rats. Int. J. Curr.Microbiol. App. Sci., 3(8):185-196.

Endo, E.H., D.A.G. Cortez, T. Ueda-Nakamura, C. V. Nakamura, and B.P. Dias Filho (2010). Potent antifungal activity of extracts and pure compound isolated from pomegranate peels and synergism with fluconazole against Candida albicans. Research in Microbiology, 161(7): 534-540.

Erhard, M. H., I. Von Quistorp, I. Schranner, A. Jüngling, B. Kaspers, P. Schmidt and R. Kühlmann (1992). Development of Specific Enzyme-Linked Immunosorbent Antibody Assay Systems for the Detection of Chicken Immunoglobulins G, M, and A Using Monoclonal Antibodies. Poultry Science, Volume 71, Issue 2, 1 February 1992, Pages 302-310.

Fadavi, A, M. Barzegar and M.H. Azizi (2006). Determination of fatty acids and total lipid content in oilseed of 25 pomegranates varieties grown in Iran. Journal of Food Composition and Analysis, 19: 676-680.

Fayed, A.M., A.A. Azoz, A. H. Zedan, and M. Basyony (2012). Effects of pomegranate peel as antioxidant supplementation on digestibility, blood biochemical and rabbit semen quality. Egy. J. Nutr. and Feeds, 15: 343-354.

Fuhrman, B, N. Volkova and M. Aviram (2005). Pomegranate juice inhibits oxidized LDL uptake and cholesterol biosynthesis in macrophages. J. Nutr. Biochem; 16: 570-576.

Gil, M.I., F.A. Tomás-Barberán, B. Hess-Pierce, D.M. Holcroft and A.A. Kader (2000). Antioxidant activity of pomegranate juice and its relationship with phenolic composition and processing. J. of Agric. and Food chem. 48(10): 4581-4589.

Jang, I.C., E.K. Jo, M.S. Bae, H.J. Lee, G.I. Jeon and E. Park (2010). Antioxidant and antigenotoxic activities of different parts of persimmon (Diospyros kaki cv. Fuyu) fruit. J. Med. Plants Res.; 4:155-160.

Jatoi, A.S., A.W. Sahota, M. Akram, K. Javed, M.H. Jaspal, J. Hussain and S. Mehmood (2013). Effect of different body weight categories on the productive performance of four close-bred flocks of Japanese quails, Coturnix coturnix japonica. J Anim Plant Sci., 23: 7-13.

Jeune, MA Louis, J. Kumi-Diaka, and J. Brown (2005). "Anticancer activities of pomegranate extracts and genistein in human breast cancer cells". J. of Medicinal Food 8.4: 469-475.

Joseph, M. M., S. R. Aravind, S. Varghese, S. Mini, and T.T. Sreelekha (2012). "Evaluation of antioxidant, antitumor and immunomodulatory properties of polysaccharide isolated from fruit rind of Punica granatum”. Molecular Medicine Reports 5.2: 489-496.

Kaneria, M.J.; M.B. Bapodara and S.V. Chanda (2012). Effect of extraction techniques and solvents on antioxidant activity of pomegranate (Punica granatum L.) leaf and stem. Food Anal. Methods, 5: 396404.

Kohno, H., R. Suzuki, Y. Yasui, M. Hosokawa, K. Miyashita and T. Tanaka (2004). Pomegranate seed oil rich in conjugated linolenic acid suppresses chemically induced colon carcinogenesis in rats. Cancer Science, 95: 481-486.

Lei, F., X.N. Zhang, W. Wang, D.M. Xing, W.D. Xie, H. Su and L.J. Du (2007). Evidence of antiobesity effects of the pomegranate leaf extract in high-fat diet induced obese mice. Int. J. Obes (Lond); 31: 10239. 


\section{Abdel-Wahab and Mosad}

Loren, D.J., N.P. Seeram, R.N. Schulman and D.M. Holtzman (2005). Maternal dietary supplementation with pomegranate juice is neuroprotective in an animal model of neonatal hypoxic-ischemic brain injure. Pediatric Res. 57:858-864.

Mady, M.S.; F.A. Tawfeek; Kh. M. Attia; Nasra B. Awadien and A.I. Abd EL-Lateif. (2016). Effect of dietary pomegranate (punica granatum) peel powder supplementation on growing rabbits performance. Egypt. Poult. Sci. Vol. (36): (1031-1047).

Mahmoud, M.H., S.S. Kassem, M.M. Abdel-Kader and F.A. El-Shobaki, (2011). How to reduce weight and keep healthy. Inter. J. of Academic Res., 3(6): 126-132.

Mass, J.L., G.L. Galletta and G.D. Stoner (1991). Ellagic acid, an anticarcinogen in fruits, especially in strawberries. Hort. Sci., 26, pp. 10-14.

McFarlin, B.K., K.A. Strohacker and M.L. Kueht (2009). Pomegranate seed oil consumption during a period of high-fat feeding reduces weight gain and reduces type 2 diabetes risk in CD-1 mice. Br. J. Nutr., 102, pp. 54-59.

Medjakovic, S. and A. Jungbauer (2013). Pomegranate: a fruit that ameliorates metabolic syndrome. Food Funct., 4: $19-39$.

Mehta, R and E.P. Lansky (2004). "Breast cancer chemopreventive properties of pomegranate (Punica granatum) fruit extracts in a mouse mammary organ culture". European J. of Cancer Prevention 13.4: 345-348.

Melo, I.L.P., E.B.T. Carvalho and J. Mancini-Filho (2014). Pomegranate seed oil (Punica Granatum L.): a source of punicic acid (Conjugated $\alpha$ - Linolenic Acid). J. of Human Nutr. and Food Sci., 2:1024.

Mirdehghan, S.H. and M. Rahemi (2007). Seasonal changes of mineral nutrients and phenolics in pomegranate (Punica granatum L.) fruit. Sci. Horti., 111(2):120 -127.

National Research Council, NRC (1994). Nutrient Requirements of Poultry. 9th revised edition. National Academy Press. Washington, D.C., USA.

Noda, Y., T. Kaneyuka, A. mori and I. Packer (2002). Antioxidant activities of pomegranate fruit extract and its anthocynidins: dephinidin, cyaniding and pelargonidin . J. Agric Food Chem. 50: 166-71.

North, M.O. (1981). Commercial Chicken Production Manual, $2^{\text {nd }}$ Edition. AVI Publishing Company Inc, USA.

Othman A., A. Ismail, A.N. Ghani and I. Adenan (2007). Antioxidant capacity and phenolic content of cocoa beans. Food Chem; 100:1523-1530.

Paglia, D.E. and W.N. Valentine (1967). Studies on the quantitative and qualitative Neu of Laboratory and Clinical Medicine 70: 158-169.

Prior R.L. and G. Cao (2000). Antioxidant phytochemicals in fruits and vegetables: Diet and health implications. Hort Science; 35(4): 589-592.

Rahmani A.H., M.A. Alsahli and S.A. Almatroodi (2017). Active Constituents of Pomegranates (Punica granatum) as Potential Candidates in the Management of Health through Modulation of Biological Activities. Pharmacog J.; 9(5): 689-95.

Rajani J., M.A. Karimi Torshizi and S.h. Rahimi (2011). Control of ascites mortality and improved performance and meat shelf-life in broilersus ing feed adjunctswith presumed antioxidant activity. Animal Feed Science Technology, 170: 239-245.

Ramstead A., I. Schepetkin, A. Robison, M. Quinn and M. Jutila (2013). Effect of oenothein B, a cyclic dimeric ellagitannin isolated from Epilobium angustifolium, on the antiviral responses of innate lymphocytes. (P4365). Journal of Immunology, 190: 183.18 (Abst).

Rosenblat, M., L. Gaidukov and O. Khersonsky (2006). The catalytic histidine dyad of high density lipoprotein-associated serum paraoxonase-1 (PON1) is essential for PON1-mediated inhibition of low density lipoprotein oxidation and stimulation of macrophage cholesterol efflux. J Biol Chem; 281:765765 . 
Saki, A. A., M. Rabet, P. Zamani and A. Yousefi (2014). The Effects of Different Levels of Pomegranate Seed Pulp with Multi-Enzyme on Performance, Egg Quality and Serum Antioxidant in Laying Hens. Iranian Journal of Applied Animal Science 4(4), 803-808.

Sarkhosh, A., Z. Zamani, R. Fatahi, H. Ghorbani and J. Hadian (2007). A review on medicinal characteristics of pomegranate (Punica granatum L.). J. Med. Plants, 6 (22), pp. 13-24.

Schubert, S.Y., E.P. Lansky and I. Neeman (1999). "Antioxidant and eicosanoid enzyme inhibition properties of pomegranate seed oil and fermented juice flavonoids". Journal of Ethnopharmacology 66.1: 11-17.

Sehm, J., D. Treutter, H. Lindermayer, H.H. Meyer and M.W. Pfaffl (2011). The influence of apple- or redgrape pomace enriched piglet diet on blood parameters, bacterial colonisation, and marker gene expression in piglet white blood cells. Food Nutr Sci 2: 366 -376.

Sharifiyan, F., A. Movahedian-Attar, N. Nili and S. Asgary (2016). Study of pomegranate (Punica granatum L.) peel extract containing anthocyanins on fatty streak formation in the renal arteries in hypercholesterolemic rabbits. Adv Biomed Res; 5:8.

SPSS (2013). IBM SPSS Statistics for Windows, Version 22.0. Armonk, NY: IBM Corp. Released 2013.

Viuda-Martos, M., J. Fernandez - Lopez and J. A. Perez Alvarez (2010). Pomegranate and its many functional components as related to human Health: Review Comprehensive Reviews in Food Fci. and Food safety Vol. 9.

Wang, Y.W., C.J. Field and J.S. Sim (2000). Dietary polyunsaturated fatty acids alter lymphocyte subset proportion and proliferation, serum immunoglobulin g concentration, and immune tissue development in chicks. Poult. Sci., 79:1741-1748.

Yagi, K. (1998). Simple assay for the level of total lipid peroxides in serum or plasma. Methods in Molecular Biology 108, 101-10.

Yamasaki, M., T. Kitagawa, H. Chujo, N. Koyanagi, E. Nishida, M. Nakaya, K. Yoshimi, H. Maeda, S. Nou, T. Iwata, K. Ogita, H. Tachibana and K. Yamada (2004). Physiological difference between free and triglyceride type conjugated linoleic acid on the immune function of C57BL6N mice. Journal of Agricultural and Food Chemistry, 2: 3644-3648.

Yamasaki, M., T. Kitagawa, N. Koyanagi, H. Chujo, H. Maeda, J. Kohno-Murase, J. Imamura, H. Tachibana and K. Yamada (2006). Dietary effect of pomegranate seed oil on immune function and lipid metabolism in mice. Nutrition, 22: 54-59.

Yan, L., Q.W. Meng and I.H. Kim (2011). The effect of an herb extract mixture on growth performance, nutrient digestibility, blood characteristics and fecal noxious gas content in growing pigs. Livestock Science, 141: 143-147.

Yassein, D.M.M., E.A. Abdallah, I.I. Ismail and A.A. Faddle (2015). Effect of Dietary Supplementation of Pomegranate Peel Powder and Butylated hydroxy Toluene on some Productive, Physiological and Immunological Parameters of Japanese Quail. Egyptian Journal of Animal Production 52 (Suppl. Issue):105-113.

Zeweil, H., S. Elnagar, S.M. Zahran and Y. Elgindy (2013). Pomegranate peel as natural antioxidant boosts bucks, fertility under Egyptian conditions. World rabbit Sci., 21: 33-39. 
تأثير إضافة قشر الرمان إلى علائق السمان الياباني على الأداء الإتتاجي ويعض صفات اللدم والمناعة خلال مرحلة

\author{
عبد الوهاب عبد الله عبد الوهاب1 و أحمد سلامه مسعد²

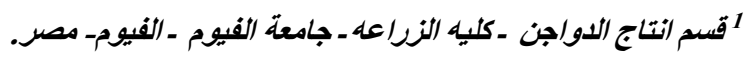 \\ 2 - مزارة الزراعة- مصر.
}

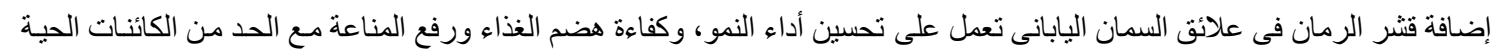

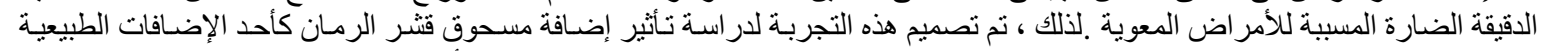

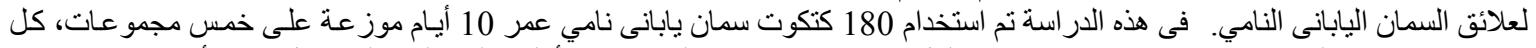

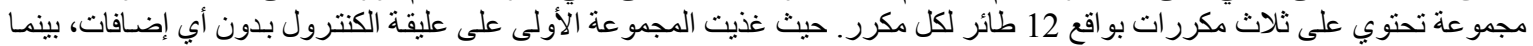

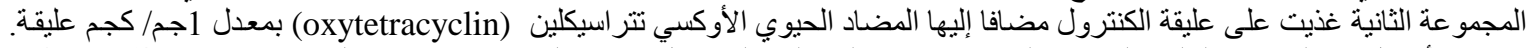

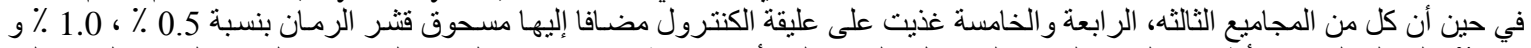

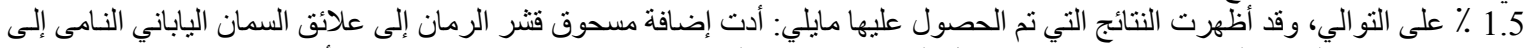

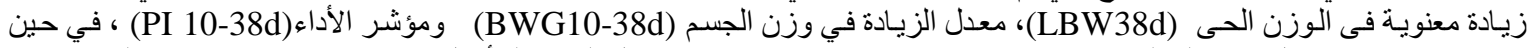

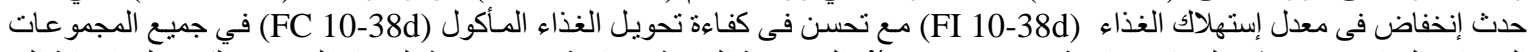

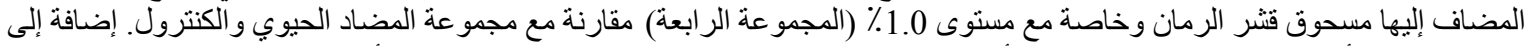

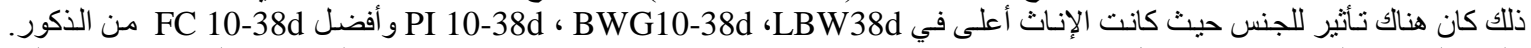

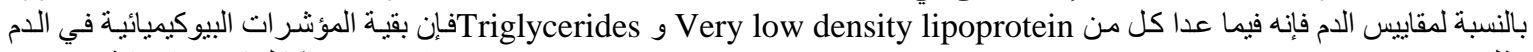
مثل High density lipoprotein و النخفضت بشكل كبير بإضافة مسحوق قشتر الرمان. وبالنسبة لمقاييس مضادات الأكسدة، باستثناء Glutathione peroxidase والاستجابات المناعية و الميكروفلورا المعوية، فيان

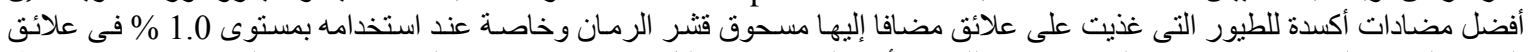

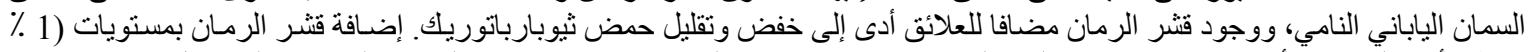

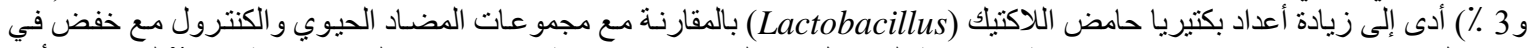

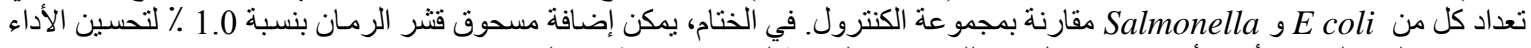
الإنتاجي و الفسيولوجي وأيضا أستخدامه كبديل جيد للمضادات الحيوية لتحفيز وتتشيط نمو السمان. 